\title{
Effect of site conditions and tree species composition on physico-chemical properties of soil environment in the Western Carpathians area
}

\section{Vavříček, J. Pecháček, G. Baláž}

Doc. Ing. Dr. Dušan Vavríček, Mendel University in Brno, Faculty of Forestry and Wood Technology, Zemédèlská 3, 61300 Brno, Czech republic, tel.: + 420545134 187, fax: + 420545211 422, e-mail: dusvav@mendelu.cz

Ing. Jan Pecháček, Mendel University in Brno, Faculty of Forestry and Wood Technology, Zemédélská 3, 61300 Brno, Czech republic, tel.: + 420545134 187,fax: + 420545211 422, e-mail:xpechace@node.mendelu.cz

\begin{abstract}
Vavříček, D., Pecháček, J., Baláž, G. 2011: Effect of site conditions and tree species composition on physico-chemical properties of soil environment in the Western Carpathians area. - Beskydy, 5 (1): 65-78

The objective of pedological research conducted in the Kněhyně-Čertův mlýn National Nature Reserve was to verify to what extent the properties of the soil environment are influenced by: a) chemistry of soil-forming substrate, b) site conditions, c) species composition of forest stand. The results of this study document that the soil taxonomic units in the area of interest are of podzol character and that the altitudinal soil zonality has not developed there. The total content of basic macrobioelements in soil-forming substrates is not in correlation with their accessible fraction in top genetic horizons of the profile depth. The results of this study also show that lead content reaches a significantly hazardous boundary level at sites of ridge stands in the exposure of northern quadrants. The soil environment under forest stands with prevailing Norway spruce (Picea abies /L./ Karst.) is enriched with C-compounds and active humus in the entire profile more than the soil under stand types with prevailing European beech (Fagus sylvatica). In top horizons of soil Norway spruce influences significantly negatively humus quality $(\mathrm{C}: \mathrm{N})$ and also the content of accessible potassium which decreases in humification horizons below the limit of $200 \mathrm{mg} \cdot \mathrm{kg}^{-1}$.
\end{abstract}

Keywords: site conditions, soil-forming substrate, species composition of forest stand, soil type, humus

\section{Introduction}

The soil component creates an essential environment for the basic physiological processes of plants and is an integral part of the forest ecosystem. Soils are formed under the frequently antagonistic action of an open set of soil-forming factors. The very top layer of soil consists of forest floor which fulfils many key functions in the forest ecosystem (Green et al. 1993). The character and parameters of humus forms significantly influence the cycle of nutrients, moisture and temperature regimes of top layers of soil. They also represent the root zone for forest tree species, influencing on-site production to a great extent (Podrázský et Remeš 2005). Other studies have also confirmed that the components of colloid humus are important factors of sorption properties of soil. Long-term disturbance of humification processes may be connected with a disorder of the nutrient status of biocoenoses and their decline (Purdon et al. 2004; Modrzyński 2003; Laughlin et Percy 1999).

Some studies aimed at vegetation-soil relations have demonstrated that in relation to the species composition forest stands substantially change the humus status and simultaneously 
nutrient content in the soil (Ulbrichová et al. 2005; Podrázský et Ulbrichová 2004; Podrázský et al. 2009), creating conditions for their persistence in an ecosystem and for the persistence of an ecosystem in the given shape or more frequently for a change in the species composition of stands (further development of the ecosystems concerned) (Van Breemen et Finzi 1998; Binkley et Giardina 1998; Finizi et al. 1998). Norway spruce has been proved to exert a degradation effect on the soil (Podrázský et Viewegh 2009; Matějka et Starý 2009). Litterfall of this tree species causes acidification of the top layer of soil (Fabianek et al. 2009, Menšík et al. 2009), and in general, lower base saturation (Binkley et Valentine 1991; Augusto et al. 2003) and in some cases a higher amount of aluminium (HagenThorn et al. 2004) were found out under Norway spruce trees.

The influence of tree litterfall on the soil diminishes with an increasing profile depth while the influence of soil-forming substrates and other pedogenetic factors, mainly of topography, becomes more intensive there. The relief in mountain areas is generally largely broken and it usually contributes to the origination of a highly heterogeneous soil environment. E.g. Philips et al. (1996) collected an extensive material showing that especially the soil catenas of distinctive texture are characterised by high diversity of soil units. In enclaves of the Kněhyně Mt. massif up to 22 soil units per 30 ha were determined (Vavř́iček et al. 2008). The buffering capacity of different forest types is able to significantly differentiate the dynamics of decline of closeto-nature and non-natural forests as well as different rate of monoculture decline in generally identical economic conditions (Posch et al. 1995; Schmidt et Herman 2004; Purdon et al. 2004).

The objective of the present study is to evaluate to what extent the properties of the soil environment in the Western Carpathians are influenced by: a) chemistry of the soil-forming substrate, b) site conditions, and c) species composition of forest stand.

\section{Method}

\section{Description of the area of interest and research plots}

The Moravian-Silesian Beskids are a pronounced mountain range of the folded and faulted structure, composed of mountain ridges in the ENE - WSW direction. The highest northern ridge composed of hard Godula sandstones sharply rises from the northern foreland of
$300-700 \mathrm{~m}$ above sea level by a high slope in the form of so called front mountains (Kněhyně, Smrk, Lysá hora, Travný). Geologically, the Moravian-Silesian Beskids are formed of flysch sediments. These are particularly Godula sandstones of the Cretaceous period and in places claystones, marlstones, conglomerates and shales (Demek et al. 1987). Cambisol is the markedly most widespread soil type. Cryptopodzols and Podzols occur at the highest locations while Fluvisols are found in the environs of streams (Průša 2001).

The massif of the National Nature Reserve (NNR) Kněhyně - Čertův mlýn is situated in the central part of the Moravian-Silesian Beskids. In this area of interest a total of 11 research plots were established with comparable site conditions; Tab. 1 shows their detailed description. The altitude of these plots is in the range of 890 - $988 \mathrm{~m}$ a.s.l. while from the aspect of soil taxonomy podzolised soil units (different subtypes of Cryptopodzols and Podzols) prevail there. In the species composition of forest stands occurring on the above-mentioned research plots European beech (Fagus sylvatica) and Norway spruce (Picea abies /L./ Karst.) are dominant tree species. Silver fir (Abies alba Mill.) is an interspersed species in these stands. The stands are incipient high forests or high forests, from the aspect of forest management these are production forests in the protection zone of the Kněhyně-Čertův mlýn NNR.

\section{Pedological survey of sites}

Site conditions (altitude, exposure, slope) were evaluated on the particular research plots; a soil pit of the depth reaching the substrate horizon $\mathrm{C}$ was dug at each site. The soil taxonomy of exposed soil profiles was described using the FAO WRB (2007) international classification. In the Results section of this paper for clearer differentiation of the intensity of podzolization processes the term Cryptopodzol is used [(according to the Taxonomic Classification System of Soils of the Czech Republic, (Němeček et al. 2001)], which corresponds to the term Entic Podzol in the used FAO WRB classification and in Tab. 1. Top horizons of soil were described according to the taxonomy of humus forms (Green et al., 1993).

\section{Collection of samples}

On each research plot soil samples were taken from one pit and from four sample squares 50 x $50 \mathrm{~cm}$ in size. From soil pits soil samples were collected from all horizons beginning with humification horizon $\mathrm{H}$ and ending with 
substrate horizon C. From each sample square 1 sample of humification horizon and 1 sample of organomineral horizon were taken. In total, on each research plot 5 samples of humification and organomineral horizons and 1 sample from each of the other subsurface, spodic and substrate horizons were collected using the abovementioned method.

\section{Laboratory methods}

Laboratory techniques in an accredited laboratory of the company Laboratoř Morava, s.r.o. included the analyses of active $\left(\mathrm{pH} / \mathrm{H}_{2} \mathrm{O}\right)$ and potential $(\mathrm{pH} / \mathrm{KCl})$ soil reaction using a $\mathrm{pH}-\mathrm{me}-$ ter with a combined glass electrode $\left(\right.$ soil/ $/ \mathrm{H}_{2} \mathrm{O}$ or $1 \mathrm{M} \mathrm{KCl}=1 / 2.5$ ), soil adsorption complex characteristics ( $\mathrm{S}$ - base content, CEC - cation exchange capacity, V - base saturation) according to Kappen (Zbíral et al., 1997), $\mathrm{H}^{+}$concentrations on the principle of $\mathrm{pH}$ double measurement (Adams et Evans 1990) and accessible mineral nutrients (Ca, Mg, K) from extracts by Mehlich II method of atomic adsorption spectrophotometry (Mehlich 1978). Phosphorus content in $\mathrm{H}$ horizons was determined by Gohler method, phosphorus content in Ae/Ep, Bs horizons was determined spectrophotometrically in a solution of ascorbic acid, $\mathrm{H}_{2} \mathrm{SO}_{4}$ and $\mathrm{Sb}^{3+}$. Oxidizable organic carbon $\left(\mathrm{C}_{\mathrm{ox}}\right)$ was determined by endothermic extraction in a chromium sulphur mixture. The combustion mixture was in surplus, the unreacted residue was determined by dead stop titration with Mohr salt. Carbon contained in humus acids (hereinafter C-HS) was determined spectrophotometrically according to characteristic absorbances in pyrophosphate. Carbon contained in humic acids (hereinafter C-HA) and carbon contained in fulvic acids (hereinafter C-FA) were detected. Based on these data the C-HA/FA ratio was calculated (Vavř́iček et al. 2006). Total nitrogen $\left(\mathrm{N}_{\mathrm{t}}\right)$ was determined by the Kjeldahl method (Zbíral et al., 1997). The sulphur content was determined on the basis of annealing and combustion in $\mathrm{HCl}$ with subsequent precipitation of sulphur by $\mathrm{BaCl}_{2}$ on $\mathrm{BaSO}_{4}$. Lead $(\mathrm{Pb})$ content was determined in the extract of $2 \mathrm{M} \mathrm{HNO}_{3}$.

\section{Statistical evaluation}

The Statistica $\mathrm{Cz}$ programme was used for a statistical evaluation. The main assessed relationship in the framework of statistical evaluation was the evaluation of correlations between the species composition of forest stands and the values of physicochemical properties of soil. The influence of soil-forming factors on soil properties was evaluated by correlation analyses. Parametric analysis of variance (ANOVA) including subsequent Scheffe's comparison was employed for the evaluation of specific differences among the particular localities. All hypotheses concerning relations among the studied variables were tested at $\mathrm{p}=0.05$.

\section{Results and Discussion}

\section{Soil taxonomic units in the studied area of Kněhyně - Čertĩv mlýn NNR}

Soils of the geomorphologically differentiated enclave Kněhyně - Čertův Mlýn are characterized by the prevailing podzolization process with the occurrence of two basic soil units, Podzols and Cryptopodzols (Tab. 1). They are influenced in places by an increased proportion of soil water in the profile and continuous process gleization at larger depths of soil profiles. The influence of the accumulation of gravitational water is not related with the altitude above sea level but it is closely connected with the geomorphological structure and with the character of substrate horizons. It is associated particularly with the foliation of disintegrating rock, content of clay fractions and consistency of deep horizons. The influence of gravitational water depth on soil-forming processes is exerted ca. in $50 \%$ of the plots. In the framework of soil-forming processes a local increase in skeleton content at various profile depths is a significant factor that conditions the development of psephitic or ranker subtypes or varieties.

The occurrence of Podzols and Cryptopodzols, which account for ca. $27 \%$ on the investigated plots, is not related with altitudinal zonation. In the area concerned Cryptopodzols occur both in locations at the lowest altitude (865 $\mathrm{m}$ a.s.l.) and in locations of ridge enclaves at the altitude of 935 - $975 \mathrm{~m}$ a.s.l. Podzols are present in the entire range of altitudinal zonation of 890 - 988 m a.s.l. Prǔša (2001) also reported that in the Moravian-Silesian Beskids the altitudinal soil zonality has developed minimally thanks to the flysch bedrock and favourable microclimate. Podzolization is an essential soil differentiation process in these locations (Vavříček et Šimková, 2000). Basic soil units of Podzols and Cryptopodzols have intermingled with each other. Intensive podzolization processes have been eliminated and attenuated in places especially due to different texture and trophicity of the bedrock, more favourable microclimate and the related lower accumulation of raw humus. $\mathrm{Hu}-$ mus form is connected with the reserve of forest floor. It is an important factor indicating mutual relations between soil and vegetation cover 
(Emmer 1999). The heterogeneity of the flysch zone is one of the main factors of a deviation that conditions the occurrence of Cryptopodzols also at higher altitudes.

All soils are characterized by great depth, with a minimum intrasoil erosion factor. The basic genetic depth oscillates between 60 and $80 \mathrm{~cm}$. The only exception is a below ridge site of the NNW exposure with modal Cryptopodzol at an altitude of $966 \mathrm{~m}$ a.s.l. where the genetic depth of soil is only $40-50 \mathrm{~cm}$. The soil taxonomic units are not conditioned by the stand type. Many studies have documented that tree species influence only the forest floor (Menšík et al. 2009, Fabianek et al.2009, Kacálek et al. 2010, Vavříček et al. 2008) while their influence decreases with an increasing exposure to climatic conditions in mountain locations. The development of organomineral and mineral horizons is a very longterm process whereas especially gradual pedogenetic changes and persisting predisposition to high heterogeneity are reflected in the dynamics of these horizons (Samec et al. 2008).

\section{Soil-forming substrates and their influence on the content of available nutrients in soil environment}

The soil units are not correlative with the unbalanced mineral strength of the soil-forming substrate. The soil substrates of rhythmic flysch are highly varied in texture and trophicity. By the character of their parameters they are significant for the below ridge length and inclination of slope and for the altitude of the site. In soil-forming substrates the values of calcium and magnesium significantly increase with the below ridge length of slope. A negative correlation was proved in the altitude that is closely correlated with the slope length. Calcium and magnesium significantly increased at higher accumulation with decreasing altitude (Tab. 2). The deep enrichment with these macrobioelements is significant, mainly at sites influenced by mixed substrates of Godula sandstones and green-grey claystones. Due to the mixed character of sedimentary rock the content of potassium as the basic element of Godula strata is significantly variable. In substrate horizons $\left(C_{1}\right)$ it ranges from the low content of $12-13 \mathrm{~g} \cdot \mathrm{kg}^{-1}$ to the level of good concentration ca. $26-27 \mathrm{~g} \cdot \mathrm{kg}^{-1}$ of potassium (Tab. 3). The low and high values were recorded both at ridge sites and in colluvial deposits.

The high mineral strength of the soil-forming substrate was observed mainly on specific plots No. 3 and No. 4 (Tab. 3). The values of all parameters are high. The levels of magnesium and calcium are very low at the other sites.

The higher trophicity of soil-forming substrates on plots No. 3 and 4 may be caused by an admixture of carbonate cement with the spot occurrence at deep layers of Turonian sandstones in this area. The total content of the basic macrobioelements in soil-forming substrates is not in significant correlation with the fraction of accessible nutrients in the other horizons (Tab. 2). In medium-deep and deeper genetic horizons the correlation is significant only between the accessible form of potassium and the iron content in substrate. The content of accessible calcium at medium depths of soil is also correlative with the content of free aluminium in substrate horizons. A significant proportion of hydrous micas (glauconite) in Godula sandstones augments the content of total potassium and iron (Vavříček et al. 2008). Combined with the cement and picrite sedimentary component calcium and oxalate iron released from weathering processes intermingle with each other.

In conditions of deep mountain soil profiles with markedly prevailing podzolization processes the influence of the mineral strength of soil-forming substrates on the values and variability of contents of accessible nutrients in the particular sequences of genetic horizons is minimum (Tab. 3). A positive feature of the flysch zone in higher mountain locations is based mainly on textural optimization and at a continuous increase in CEC on the sorption of basic nutrients.

\section{Topography and its influence on top layers of soil}

A significant influence of the slope inclination was reflected in humification and organomineral horizons only in parameters of soil reaction and accessible magnesium content (Tabs. 4, 7). The $\mathrm{pH}$ value and the value of accessible magnesium decrease with the higher value of slope inclination implying predisposition to more intensive erosion. The content of accessible calcium nearly copies these characteristics. In mountain locations at a high precipitation amount the slope inclination may have an influence on the eluviation of bivalent bases that diminish their proportion in the sorption complex. C-compounds in humification horizons are not influenced by the slope inclination. The slope exposure has a significant influence only on lead contamination. Deposition of these substances dates back to the past to historical airpollution stress. 


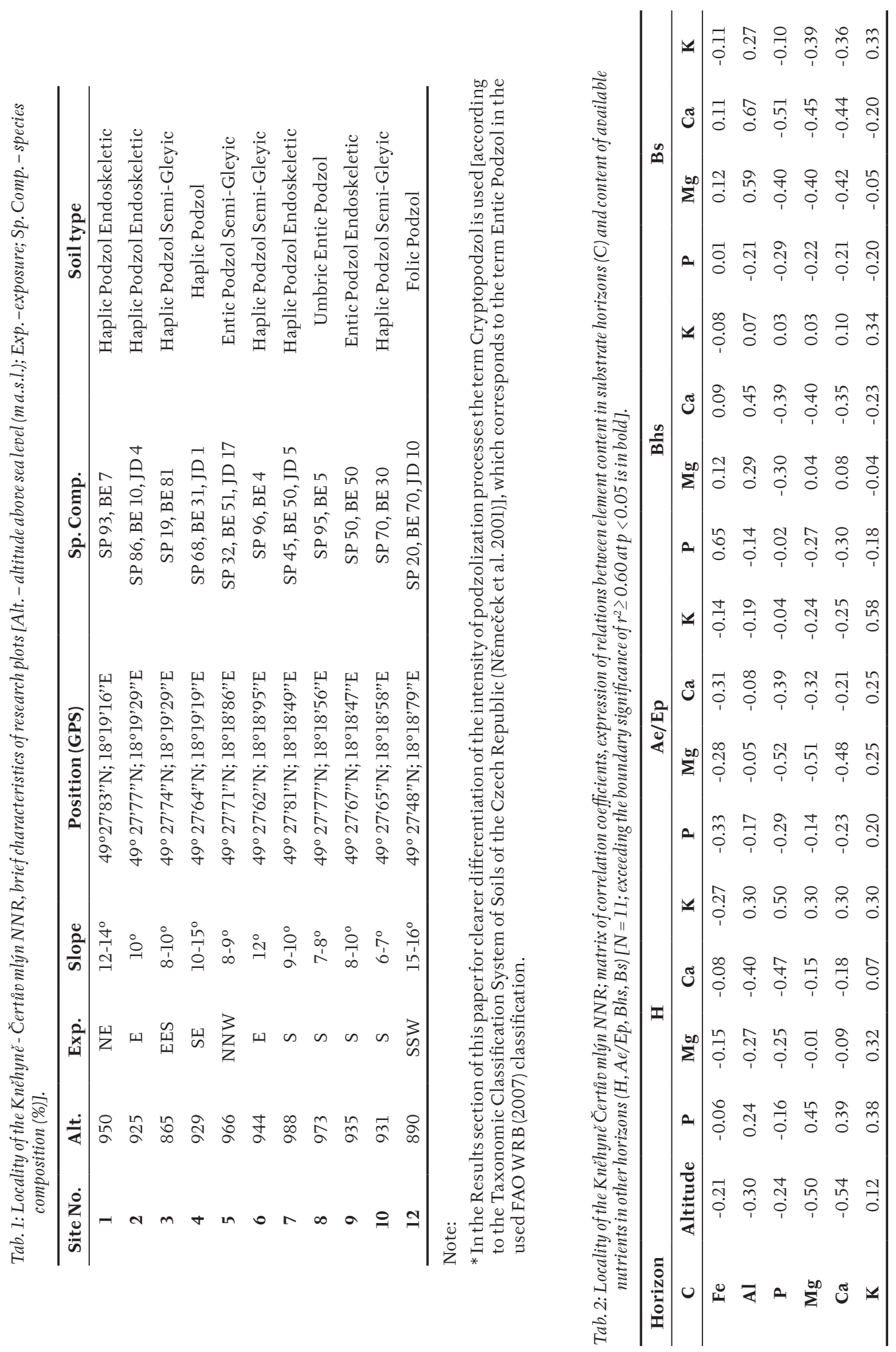


Tab. 3: Locality of the Knèhyně- Čertiov mlýn NNR, physicochemical and chemical properties of C horizons in 2010 $[\mathrm{Fe}, \mathrm{Al}(\mathrm{g} / \mathrm{kg}) ; \mathrm{P}, \mathrm{Mg}, \mathrm{Ca}, \mathrm{K}(\mathrm{mg} / \mathrm{kg})]$.

\begin{tabular}{ccccccccc}
\hline Site No. & $\mathbf{p H} / \mathbf{H}_{\mathbf{2}} \mathbf{O}$ & $\mathbf{p H} / \mathbf{K C l}$ & $\mathbf{F e}$ & $\mathbf{A l}$ & $\mathbf{P}$ & $\mathbf{M g}$ & $\mathbf{C a}$ & $\mathbf{K}$ \\
\hline $\mathbf{1}$ & 4.43 & 3.94 & 2.81 & 4.29 & 517 & 8440 & 4970 & 13200 \\
$\mathbf{2}$ & 4.32 & 3.99 & 3.25 & 3.1 & 238 & 3358 & 1321 & 16848 \\
$\mathbf{3}$ & 4.55 & 3.98 & 2.67 & 5.56 & 662 & 44400 & 23700 & 26000 \\
$\mathbf{4}$ & 4.49 & 4.11 & 2.96 & 4.4 & 430 & 40800 & 23100 & 25000 \\
$\mathbf{5}$ & 4.20 & 4.06 & 1.45 & 1.9 & 575 & 4350 & 4600 & 25100 \\
$\mathbf{6}$ & 4.31 & 3.98 & 7.51 & 7.67 & 490 & 4519 & 905 & 19714 \\
$\mathbf{7}$ & 4.18 & 3.68 & 1.88 & 10.4 & 321 & 7807 & 1105 & 23837 \\
$\mathbf{8}$ & 4.53 & 4.16 & 2.44 & 4.26 & 180 & 5207 & 872 & 21722 \\
$\mathbf{9}$ & 4.36 & 4.06 & 1.32 & 6.36 & 275 & 4823 & 1310 & 15075 \\
$\mathbf{1 0}$ & 4.27 & 3.86 & 1.26 & 3.78 & 216 & 1242 & 3156 & 26519 \\
$\mathbf{1 2}$ & 4.53 & 4.12 & 4.65 & 20.7 & 250 & 3053 & 1739 & 11948 \\
\hline
\end{tabular}

Higher values of lead content in holoorganic horizons were measured mainly in exposures of northern quadrants, oriented towards the Ostrava industrial agglomeration. These results correspond with conclusions of Sparks (2003) and Šály (1998), who considered the relief as one of the most important factors in the formation of mountain soils. The broken relief causes the patchy action of the particular components of ecotope and climatope, and related changes in the soil environment, even to short distances (Samec et al. 2008).

\section{Humification horizons and their influencing by the species composition of forest stand}

Humification horizons are very well developed at sites of mountain locations. Their formation and origination are a part of the polyfactorial problem where the essential role is played by a sufficient supply of the organic component from litterfall of the tree species of stand types and by climatic conditions of the area. The depth of humification horizon is not related either with the species composition of stand type or with the terrain relief. Only historically deposited contaminants of sulphur and lead are significantly accrued with greater depth (Tab. 4). Their levels are the highest at sites of ridge localities of northern quadrants without the influence of stand type or potentially of the soil taxonomic unit. Lead exceeding the limit of $400 \mathrm{mg} \cdot \mathrm{kg}^{-1}$ (Tab. 5) reaches the boundary level of hygienic limits $60 \mathrm{mg} \cdot \mathrm{kg}^{-1}$ of mineral soils. We cannot speak about the values of ecological background in this case. The soil reaction oscillates on the level of highly acidic to acidic soils (Tab. 5). The values are quite normal for humification horizons characterized by a podzolization process in the mountain zone.

Cation exchange capacity is unbalanced (Tab. 5). The values are very high in organic horizons. The relations are significant mainly from the aspect of water and macrobioelement retention. The limits of $1000 \mathrm{mmol} \cdot \mathrm{kg}^{-1}$ are exceeded almost on $65 \%$ of the plots. This capacity is closely related with the content of humus, a long-term source of C-compounds (Waring et Running 1998) that are on a high level in humification horizons (ca. $27-36 \%$ ). In the given area of the Beskids flysch they are not correlative with the tree species composition of stand types. Total carbon correlates with total content of active humus (Tab. 4) when some independent fractions, e.g. humic acids and fulvic acids, reach the values up ca. to $3000-4000 \mathrm{mmol} \cdot \mathrm{kg}^{-1}$. Humus substances under Norway spruce are more mobile and penetrate to deeper soil layers than under stands with a significant admixture of European beech. Norway spruce is a tree species that significantly increases maximum sorption (Tab.4).

Cation exchange capacity (CEC) of humification horizons is influenced to a greater extent by the fraction of humic acids that show a highly correlative relation with CEC (Tab. 4).

In the species composition of the particular localities CEC is in correlation with the Norway spruce proportion. The HA and HA/FA ratio rises with the increasing proportion of spruce. A higher content of humic acids under spruce stands than under beech stands was reported by Matějka et Starý (2009). The evaluation of humus quality according to the HA/FA ratio is problematic in humification horizons and need not fulfil the hypothesis presented by 


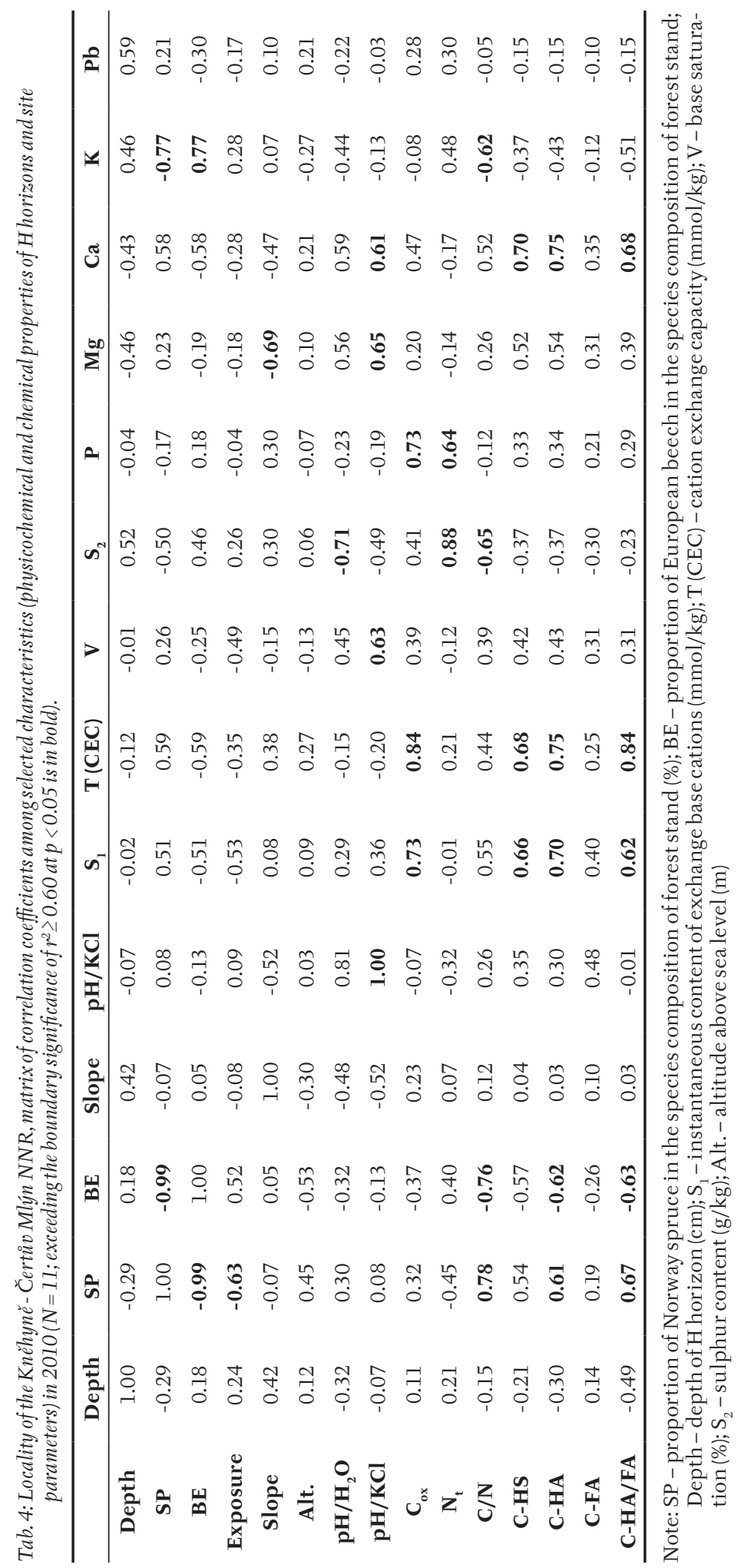




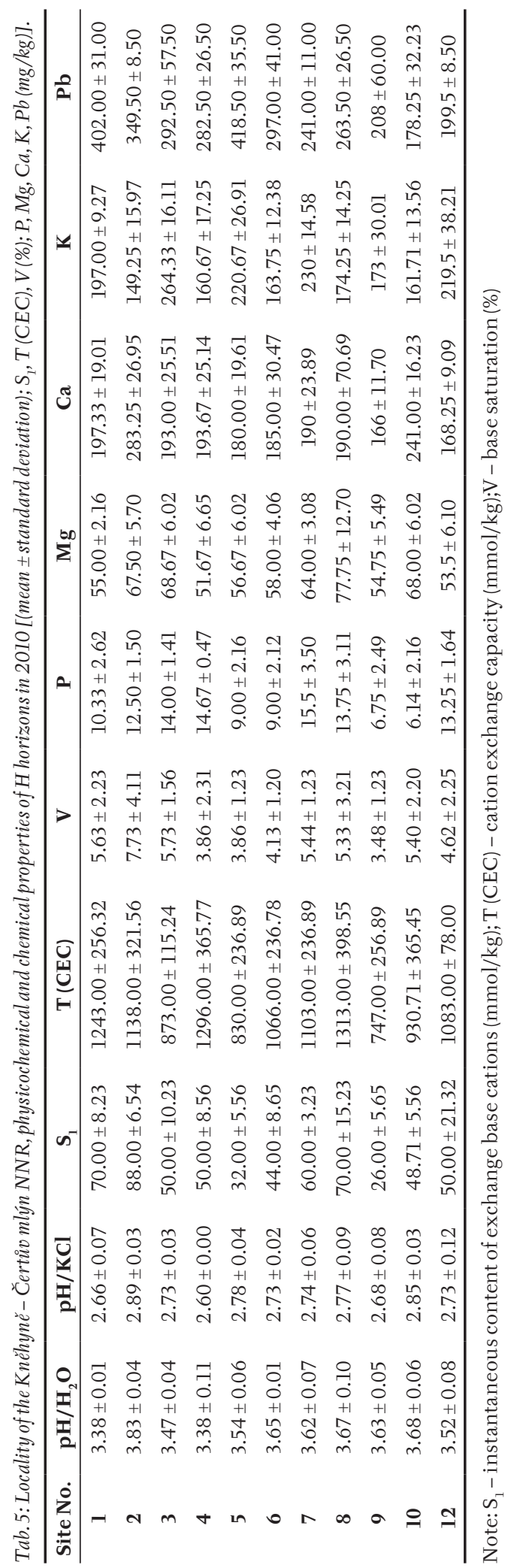


Tab. 6: Locality of the Knèhyně- Čertưv mlýn NNR, physicochemical and chemical properties of Ae/Ep horizons in 2010 [(mean \pm standard deviation); P, $M g, C a, K, P b(m g / k g)]$.

\begin{tabular}{cccccc}
\hline Site No. & $\mathbf{P}$ & $\mathbf{M g}$ & $\mathbf{C a}$ & $\mathbf{K}$ & $\mathbf{P b}$ \\
\hline $\mathbf{1}$ & $11.33 \pm 2.05$ & $30.67 \pm 2.62$ & $200.00 \pm 83.54$ & $22.00 \pm 2.45$ & $10.40 \pm 5.65$ \\
$\mathbf{2}$ & $12.00 \pm 5.83$ & $35.75 \pm 1.92$ & $160.00 \pm 30.63$ & $37.75 \pm 5.36$ & $19.00 \pm 4.33$ \\
$\mathbf{3}$ & $7.67 \pm 1.25$ & $31.00 \pm 2.45$ & $137.00 \pm 8.60$ & $39.00 \pm 5.10$ & $26.00 \pm 15.11$ \\
$\mathbf{4}$ & $2.67 \pm 1.33$ & $27.00 \pm 7.40$ & $126.33 \pm 13.16$ & $25.67 \pm 23.37$ & $9.58 \pm 24.55$ \\
$\mathbf{5}$ & $9.00 \pm 1.41$ & $37.00 \pm 2.94$ & $141.00 \pm 6.38$ & $57.67 \pm 7.41$ & $71.70 \pm 23.60$ \\
$\mathbf{6}$ & $3.00 \pm 1.41$ & $41.25 \pm 7.33$ & $157.00 \pm 4.64$ & $57.50 \pm 23.48$ & $28.90 \pm 11.23$ \\
$\mathbf{7}$ & $21.5 \pm 2.18$ & $44.25 \pm 3.77$ & $199.75 \pm 10.18$ & $60.75 \pm 11.32$ & $33.60 \pm 8.65$ \\
$\mathbf{8}$ & $24.50 \pm 11.32$ & $38.25 \pm 2.59$ & $152.50 \pm 7.63$ & $39.00 \pm 9.35$ & $41.40 \pm 12.36$ \\
$\mathbf{9}$ & $2.75 \pm 0.83$ & $46.25 \pm 4.97$ & $196.50 \pm 11.72$ & $51.00 \pm 5.87$ & $37.60 \pm 8.65$ \\
$\mathbf{1 0}$ & $6.50 \pm 1.12$ & $60.00 \pm 3.56$ & $672.00 \pm 6.35$ & $58.75 \pm 12.5$ & $85.35 \pm 11.12$ \\
$\mathbf{1 2}$ & $4.00 \pm 1.58$ & $35.25 \pm 0.83$ & $201.75 \pm 20.91$ & $29.75 \pm 2.86$ & $8.71 \pm 2.65$ \\
\hline
\end{tabular}

some authors (Zacanda et al. 2003, Slepetiene et Slepetys 2005) that humus quality rises with the increasing content of humic acids. In the analyses of C-HA fraction the determined values are often distorted by an admixture of lignin which has a higher proportion (18\%) in spruce needles than in litterfall from beech leaves (12\%). For this reason humus quality decreases with the increasing proportion of spruce in the species composition of forest in spite of the higher C-HA content.

The instantaneous content of exchangeable base cations (hereinafter $\mathbf{S}$ ) is quite variable on the studied plots (Tab. 5) and fluctuates there in the range of low to medium-high values. Similarly like in CEC, a close correlation with the content of humus substances $\left(\mathrm{C}_{\mathrm{ox}}\right)$ and humic acids (C-HA) was found out as documented in Table 4. With an increase in these characteristics the $S$ value also increased. The influence of the species composition on this variable was not proved as documented by the low value of correlation coefficient in Table 4.

Base saturation of humification horizons coincides with the site of Podzols (BS = $3.7-7.7 \%$; Tab. 5). Similarly low values of this parameter were also recorded in the Moravian-Silesian Beskids by other researchers (Pavlů et al. 2007; Barszcz et Malek 2008).

Base saturation correlates with the values of a very low exchange reaction of soil that is on the level of mountain Podzols $2.6-2.9 \mathrm{pH} / \mathrm{KCl}$. Similar values were reported by Huber et al. (2002), who recorded $2.8-3.0 \mathrm{pH} / \mathrm{KCl}$ in humification horizons and $3.0 \mathrm{pH} / \mathrm{KCl}$ in organomineral horizons that were found out in dystric Cambisols at intermediate locations of Höglwald in Germany. At very low values the base saturation (BS) is more increased in deep horizons under stands with a higher proportion of Norway spruce.

Base saturation of humification horizons coincides with the site of Podzols ( $\mathrm{BS}=3.7-7.7 \%$; Tab. 5). Similarly low values of this parameter were also recorded in the Moravian-Silesian Beskids by other researchers (Pavlů et al. 2007; Barszcz et Malek 2008). Base saturation correlates with the values of a very low exchange reaction of soil that is on the level of mountain Podzols $2.6-2.9 \mathrm{pH} / \mathrm{KCl}$. Similar values were reported by Huber et al. (2002), who recorded 2.8 - $3.0 \mathrm{pH} / \mathrm{KCl}$ in humification horizons and 3.0 $\mathrm{pH} / \mathrm{KCl}$ in organomineral horizons that were found out in dystric Cambisols at intermediate locations of Höglwald in Germany. At very low values the base saturation (BS) is more increased in deep horizons under stands with a higher proportion of Norway spruce.

Sulphur correlates with the content of nitrogen (Tab. 4), with which it is bound especially to amino acids. In the cases concerned its fraction is mostly of organic character. It is not connected with historically exposed sites like lead.

Humus quality described by the $\mathbf{C}: \mathbf{N}$ ratio decreases parallelly with a higher proportion of spruce. Nitrogen content in relation to carbon content is the main indicator of biomass decomposition. The close qualitative relationship of the value of $\mathrm{C} / \mathrm{N}$ ratio follows from the soil transformation of nitrogen (Cote et al. 2000). Plots with the spruce proportion higher than $85 \%$ belong to slightly risky categories when the C:N ratio increases above the value 20. At these sites undesirable deceleration of the transformation and mineralization of organic substances takes place. Humus quality and deteriorates with a higher proportion of spruce. On the 
contrary, with an increasing proportion of beech this spruce effect is eliminated and humus quality improves to an optimum level of C:N = 15-18 (Fig. 1), which was defined by Hedde et al. (2008) at a C:N ratio $=16$ in beech stands of Normandy, France. The negative influence of spruce on a C:N ratio was also documented in other studies (Fabianek et al. 2009; Menšík et al. 2009). These authors established research plots in the Drahanská vrchovina hills in beech and spruce stands and in a mixed stand. The C:N ratio was found to be statistically significantly higher in spruce stands than in beech stands. The C:N ratio in a mixed stand was between these values.

The main nutrient content in the given horizon mostly show optimum values (Tab. 5). Phosphorus contents fluctuate in the range of $9-16 \mathrm{mg} \cdot \mathrm{kg}^{-1}$ while magnesium contents are on the lower boundary of the optimum, especially when they decrease below the limits of $55 \mathrm{mg} \cdot \mathrm{kg}^{-1}$. Calcium in humification horizons is included in a good classification category unlike the findings of Novotný et al. (2008) and Barszcz et Małek (2008), who reported very low contents of this nutrient in top layers of soil in the Moravian-Silesian Beskids. Accessible phosphorus is an important element bound to humus substances. Its content in a humification horizon rises with the increasing proportion of active humus and simultaneously with the increasing value of CEC (Tab. 4). This relationship was confirmed also in conditions of the tableland of the Krušné hory Mts. (Vavř́ičck et al., 2010, 2006).

In humification horizons only potassium is correlative with stand types. Its content in soil increases significantly with a higher proportion of European beech. In this relation Norway spruce

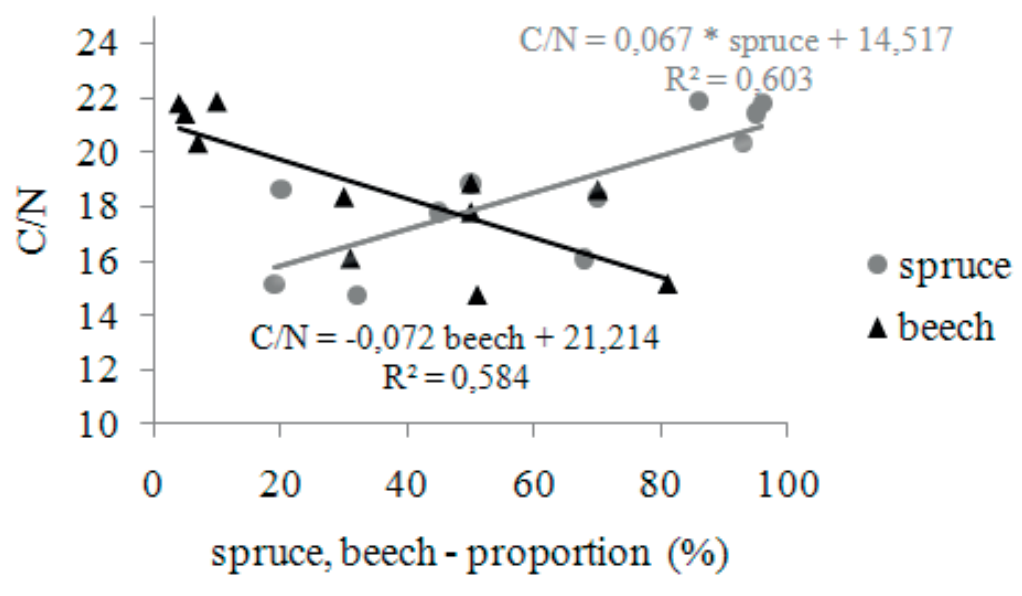

Fig 1: Locality of the Kněhyně - Čertův Mlýn NNR: the correlation between the proportions of selected tree species in the species composition of stands and the C/N ratio in humification horizon H in 2010.

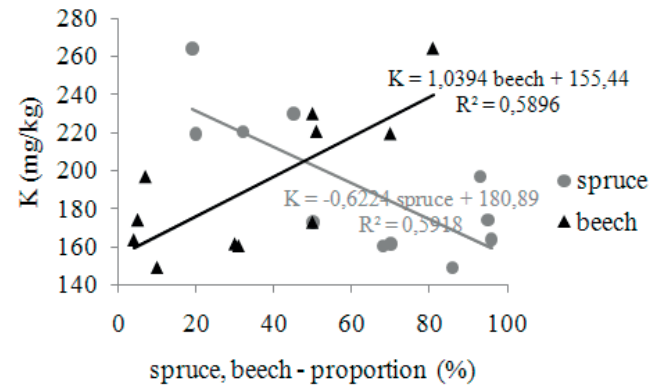

Fig. 2: Locality of the Knèhyně - Čertuiv Mlýn NNR: the correlation between the proportions of selected tree species in the species composition of stands and potassium content in humification horizon H in 2010.

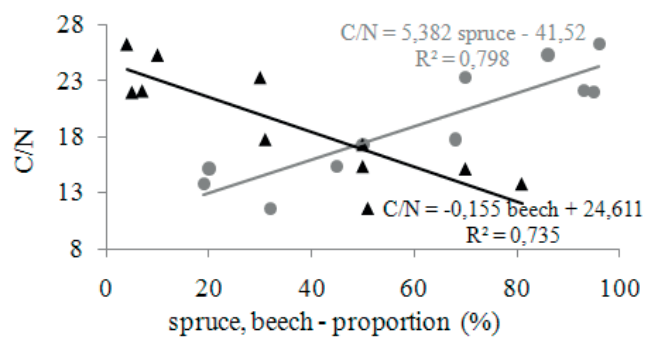

- spruce $\Delta$ beech

Fig. 3: Locality of the NPR Knèhyně - Čertuiv Mlýn NNR: the correlation between the proportions of selected tree species in the species composition of stand and the $\mathrm{C} / \mathrm{N}$ ratio in organomineral horizon Ae/Ep in 2010. 
Tab. 7: Locality of the Knèhyně- Čertův Mlýn NNR, matrix of correlation coefficients among selected characteristics (physicochemical and chemical properties of Ae/Ep horizon and site parameters) in 2010 ( $N=11$; exceeding the boundary significance of $r^{2} \geq 0.60$ at $p<0.05$ is in bold).

\begin{tabular}{lccccccccc}
\hline & $\mathbf{S P}$ & $\mathbf{B E}$ & $\mathbf{S l o p e}$ & $\mathbf{p H} / \mathbf{K C l}$ & $\mathbf{P}$ & $\mathbf{M g}$ & $\mathbf{C a}$ & $\mathbf{K}$ & $\mathbf{P b}$ \\
\hline SP & 1.00 & $\mathbf{- 0 . 9 9}$ & -0.07 & -0.11 & 0.25 & 0.09 & 0.09 & -0.11 & -0.06 \\
$\mathbf{B E}$ & $\mathbf{- 0 . 9 9}$ & 1.00 & 0.05 & 0.03 & -0.27 & -0.06 & -0.05 & 0.08 & 0.02 \\
Quadrant & 0.09 & 0.03 & -0.44 & -0.27 & 0.08 & 0.41 & 0.20 & 0.48 & 0.27 \\
Exposure & $\mathbf{- 0 . 6 3}$ & 0.52 & $\mathbf{- 0 . 0 8}$ & 0.44 & -0.05 & 0.16 & 0.03 & 0.33 & 0.44 \\
Slope & -0.07 & 0.05 & 1.00 & $\mathbf{- 0 . 6 6}$ & -0.37 & -0.57 & -0.40 & -0.58 & $\mathbf{- 0 . 7 7}$ \\
Alt. & 0.45 & -0.53 & -0.30 & 0.22 & 0.60 & 0.26 & -0.02 & 0.42 & 0.32 \\
pH/KCl & -0.11 & 0.03 & $\mathbf{- 0 . 6 6}$ & 1.00 & 0.22 & 0.47 & 0.52 & 0.31 & $\mathbf{0 . 7 6}$ \\
C & 0.46 & -0.44 & -0.52 & 0.24 & -0.08 & $\mathbf{0 . 7 9}$ & 0.57 & $\mathbf{0 . 6 8}$ & $\mathbf{0 . 6 3}$ \\
N & -0.12 & 0.09 & $\mathbf{- 0 . 6 3}$ & 0.45 & -0.09 & $\mathbf{0 . 7 0}$ & 0.36 & $\mathbf{0 . 9 0}$ & $\mathbf{0 . 8 4}$ \\
C/N & $\mathbf{0 . 8 9}$ & $\mathbf{- 0 . 8 6}$ & -0.03 & -0.11 & 0.02 & 0.25 & 0.28 & -0.08 & -0.08 \\
C-HS & 0.32 & -0.33 & $\mathbf{- 1 . 4 2}$ & 0.54 & 0.30 & $\mathbf{0 . 7 2}$ & 0.50 & $\mathbf{0 . 6 1}$ & $\mathbf{0 . 7 8}$ \\
C-HA & 0.35 & -0.34 & $\mathbf{- 0 . 7 0}$ & 0.49 & 0.19 & $\mathbf{0 . 7 5}$ & $\mathbf{0 . 6 1}$ & 0.58 & $\mathbf{0 . 7 5}$ \\
C-FA & 0.25 & -0.28 & $\mathbf{- 0 . 7 8}$ & 0.57 & 0.37 & $\mathbf{0 . 6 6}$ & 0.37 & $\mathbf{0 . 6 2}$ & $\mathbf{0 . 7 6}$ \\
C-HA/FA & 0.20 & -0.12 & 0.19 & -0.24 & -0.36 & 0.11 & 0.36 & -0.13 & -0.11 \\
\hline
\end{tabular}

Note: the abbreviations of variables are explained below Tab. 4.

has an adverse effect on the concentration of accessible potassium (Fig. 2). It shows a negative correlation when potassium decreases below the optimum level of $200 \mathrm{mg} \cdot \mathrm{kg}^{-1}$. This decrease is pronounced mainly at sites with the Norway spruce proportion higher than $60 \%$. Different contents of potassium in stands with spruce and beech were also reported by other authors. Unlike our finding they reported a positive influence of beech on the content of other nutrients such as calcium or magnesium. E.g. Podrázský et al. (2005) compared nutrient content in humification horizons in beech and spruce stands. In the uplands Českomoravská vrchovina (Žákova hora NNR) beech was found to have a positive influence on the representation of main nutrients in forest floor horizons.

This hypothesis was confirmed by the study of Kacálek et al. (2010), who evaluated the soilimprovement influence of tree species on the formation of forest floor in the afforestation of agricultural lands at the foothills of the Orlické hory Mts. Matějka et Starý (2009) laid out an experiment in the Šumava Mts., where the condition of top soil layers was compared under spruce and beech stands. In their study these authors reported a higher content of magnesium under beech stands. Similar results were obtained by Pavlů et al. (2007), who determined a higher amount of magnesium and calcium under beech stands in the Jizerské hory Mts. compared to spruce stand.
Organomineral horizons and their influencing by the species composition of forest stand

The contents of main nutrients in these horizons reach medium-low values. The locally hazardous content of magnesium in the fraction of holoorganic horizons is eliminated there by the concentration of $30-50 \mathrm{mg} \cdot \mathrm{kg}^{-1}$ (Tab. 6). Similarly low reserves were also documented in other studies from the area of the MoravianSilesian Beskids (Pavlů et al. 2007, Barsczc et Małek 2008). Spruce may be one of the factors causing the above-mentioned degradation because it shows a negative, though insignificant, correlation with all macrobioelements (Tab. 7). In these horizons continuous impairment of humus quality occurs on the level of a highly significant positive correlation. As a result of spruce admixture the $\mathbf{C}: \mathbf{N}$ ratio in epipedons increases to ca. 23-26 (Fig. 3). A similar C/N ratio 23-27 was reported by Vesterdal et al. (1995) in the southern Denmark. A significantly negative influence of spruce on the $\mathrm{C} / \mathrm{N}$ ratio in organomineral horizons was also documented in the study of Kacálek et al. (2010); a degradation influence of spruce on humus quality was also observed by Podrázský et al. (2005) and Emmett et al. (1998) reported the critical value of the $\mathrm{C} / \mathrm{N}$ ratio in coniferous stands to be ca. 24. Spruce is a significant degradation element for sites at higher locations of the flysch zone that may be substantially eliminated by an admixture of beech at its minimum proportion of ca. $40 \%$. 


\section{Conclusion}

The soil taxonomic units in the Kněhyně Čertův Mlýn area are of Podzol type and do not correlate with altitudinal zonation whereas $50 \%$ of the plots are influenced by a deep gleization process mainly of substrate horizons. These are deep soils $(>60 \mathrm{~cm})$ that are not exposed to intrasoil intraskeletal erosion in spite of the locally increased skeleton content.

The mineral strength of substrate horizons oscillates in very low to good quality classes where the total content of magnesium and calcium correlates with slope length and decreasing altitude above sea level. The total content of basic macrobioelements in soil-forming substrates is not correlative with their accessible fraction in genetic horizons of the profile depth.

The soil environment under stands with dominant Norway spruce is enriched with C-compounds and active humus in the entire profile significantly more than the soil under stand types with dominant European beech. In top horizons of soil Norway spruce influences significantly negatively humus quality (C:N) and also the content of accessible potassium which decreases in humification horizons below the

\section{References:}

Augusto, L., Dupouey, J. L., Ranger, J. 2003: Effects of tree species on understory vegetation and environmental conditions in temperate forests. Annals of Forest science, 60: 823-831.

BARSZcZ, J., MAŁeK, S. 2008: Stability of Norway spruce (Picea abies /L./ Karst.) stands in the Beskid Ślaśki and beskid Žywiecki Mts. from the aspect of their nutrition status. Journal of Forest Science, 54 (2): 41-48.

Binkley, D., Valentine, D. 1991: Fifty-year biogeochemical effects of green ash, white pine, and Norway spruce in a replicated experiment. Forest Ecology and Management, 40: 13-25.

BinKLey, D., Giardina, C. 1998: Why do tree species affect soil? The Warp and Woof of treesoil interactions. Biogeochemistry, 42: 89-106.

Cote, L., Brown, S., Pare, D., Fyles, J., Bauhaus, J. 2000: Dynamics of carbon acid nitrogen mineralization in relation to the stand type, stand age and soil texture in the boreal mixed wood. Soil Biology and Biochemistry, 32: 1079-1090.

Demeк, J. 2005: Geomorfologie českých zemí. NČSAV Praha: 196 s. limit of $200 \mathrm{mg} \cdot \mathrm{kg}^{-1}$. Spruce is in a negative, though insignificant, correlation with the other elements.

Lead content reaches a significantly hazardous boundary level at sites of ridge stands in the exposure of northern quadrants. It is a result of the deposition of contaminants from the Ostrava industrial agglomeration that lasted by the eighties of the last century.

To ensure a higher proportion of European beech in the framework of transformation of the particular stand types of mountain forest to close-to-nature forest is an essential measure underlying revitalisation of the soil environment of the $6^{\text {th }}-7^{\text {th }}$ forest altitudinal zone in the flysch zone of the Moravian-Silesian Beskids. To eliminate the degradation influence of spruce monocultures and to optimise soil parameters it is necessary to increase the proportion of European beech in the species composition to $40 \%$ at least.

\section{Acknowledgement:}

The paper was supported by the Ministry of Education, Youth and Sports of the Czech Republic, Project No. MSM6215648902

Emmer, I. M. 1999: Methodology of humus form research. Lesnictví-Forestry, 44: 16-22.

Emmet, B. A., Boxman, D., Bredemeier, M., Gundersen, P., KJonaAs, O. J., Moldan, F., Schleppi, P., Tietama, A., Wright, R. F. 1998: Predicting of the efectness of atmospheric nitrogen deposition in conifer stands. Evidence from the NITREX ecosystem scale experiments. Ecosystem, 1: 352-360

Fabiánek, T., Menšǐ́, L., TomášKovâ, I., KulhavÝ, J. 2009: Effects of spruce, beech and mixed commercial stand on humus conditions of forest soils. Journal of Forest Science, 55 (3): 119-126.

Finzi, A. C., Van Breemen, N., Canham, C. 1998: Canopy tree-soil interactions within temperate forests. Species effects on soil carbon and nitrogen. Ecological Applications, 8: 440-446.

Hedde, M., Aubert, M., Decaens, T., Bureau, F. 2008: Dynamic of soil carbon in a beachwood chronosequence forest. Forest Ecology and Management, 255: 193-202.

Green, R. N., Trowbridge, R. L., KlinKA, K. 1993: Towards a Taxonomic Classifications of Humus Forms. Forest Science, 39 (1): 36-55. 
Hagen-Thorn, A., Callesen, I., Armolaitis, K., Nihlgard, B. 2004: The impact of six European tree species on the chemistry of mineral topsoil in forest plantations on former agricultural land. Forest Ecology and Management, 195: 373-384.

HrušKa, J., Cudlín, P., KRÁM, P. 2001: Relationship between Norway spruce status and soil water base cations/aluminum ratios in the Czech Republic. Water, Air, and Soil Pollution, 130: 983-988.

HruŠKA, J., KRÁM, P. 2003: Modelling long-term changes in stream water and soil chemistry in catchments with contrasting vulnerability to acidification (Lysina and Pluhuv Bor, Czech Republic). Hydrology and Earth System Sciences, 7: 525-539.

HrušKA, E. 2005: Změna poměru bazických kationů a hliníku v půdním roztoku jako příčina poškození smrkových porostů [A change in the ratio of base cations to aluminium in the soil solution as a cause of damage to spruce stands]. In: HrušKA, J., Ciencala, E. (eds). Dlouhodobá acidifikace a nutriční degradace lesních puid - limitujícífaktor současného lesnictví [Long-term acidification and nutrition degradation of forest soils a limiting factor of the present forestry]. Praha, Česká geologická služba: 119-121.

HrušKa, J., Ciencala, E. (eds.) 2005: Dlouhodobá acidifikace a nutriční degradace lesnich puid-limitující faktor současného lesnictví [Long-term acidification and nutrition degradation of forest soils - a limiting factor of the present forestry]. Praha, Česká geologická služba: $153 \mathrm{pp}$.

Huber, C., Oberhauser, A., Kreutzer, K. 2002: Deposition of amonia to the forest floor under spruce and beech at the Hoglwald site. Plant and Soil, 240: 3-11.

Hurt, V., Peñáz, J. 2010: Possibilities of assesing the condition of cultivated spruce stands intended for transformation to close-nature forests as exemplified by supraregional biocentre-the first stage. Beskydy: The Beskids bulletin, 3 (2): 139-150.

IUSS Working Group WRB. 2007: World Reference Base for Soil Resources 2006, first update 2007. World Soil Resources Reports No. 103. FAO, Rome. 155 pp.

KacÁlek, D., Novák, J., Bartoš, J., Slodičák, M., Balcar, V., Černohous, V. 2010: Vlastnosti nadložního humusu a svrchní vrstvy půdy ve vztahu $\mathrm{k}$ druhům dřevin [Forest-floor humus and topsoil properties related to forest-tree species]. Zprávy lesnického výzkumu, 55 (1): 19-25.
Mclaughlin, S. B., Percy, K. E. 1999: Forest health in North America: some perspectives on potential roles of climatic and air pollutions. Water, Air and Soil Pollution, 116: 151-197.

MatěJKa, K., StARÝ, J. 2009: Differences in top soil features between beech mixture and Norway spruce Forests of the Šumava Mts. Journal of Forest Science, 55 (12): 540-555.

MenLich, A. 1978: New extractant for soil test evaluation of phosphorus, potassium, magnesium, calcium, sodium, manganese and zinc. Communications in Soil Science and Plant Analysis, 9 (6): 477-492.

Menšík, L., Fabianek, T., Tesař, V., Kulhavý, J. 2009: Humus conditions and stand characteristics of artificially established young stands in the process of the transformation of spruce monocultures. Journal of Forest Science, 55 (5): 215-223.

Modrzyński, J. 2003. Defoliation of older Norway spruce (Picea abies /L./ Karst.) stands in Polish Sudety and Carpathian Mountains. Forest Ecology and Management, 181: 289-299.

NĚMEČEK, J. a kol. 2001. Taxonomický klasifikační systém půd České republiky. ČZU Praha, VÚMOP Praha: 78 s.

Novotný, R., Lachmanová, Z., ŠrámeK, V., VorTELOVÁ, L. 2008: Air pollution load and stand nutrition in the Forest District Jablunkov, part Nýdek. Journal of Forest Science, 54 (2): 49-54.

Pavlů, L., BorŮvka, L., Nikodém, A., RohošKová, M., Penížek, V. 2007: Altitude and Forest Type Effects on Soils in the Jizera Mountains Region. Soil and Water Research, 2 (2): 35-44.

Phillips, J. D., Perry, D., Garbee, A. R., Carey, K., Stein, D., Morde, M. B., Sheehy, J. A. 1996: Deterministic uncertainty and complex pedogenesis in some Pleistocene dune soils. Geoderma, 73: 147-164.

PodráZský, V., UlbrichovÁ, I. 2004: Restoration of forest soils on reforested abandoned agricultural lands. Journal of Forest Science, 50 (6): 249-255.

PodráZský, V., VieWEgh, J. 2005: Comparison of humus form state in the beech and spruce parts of the Žákova hora National Nature Reserve. Journal of Forest Science, 51 (Special Issue): 29-37.

Podrázský, V., ReMeš, J. 2005: Effect of forest tree species on the humus form state at lower altitudes. Journal of Forest Science, 51 (2): 60-66.

PodrÁZsKÝ, V., REMEš, J. 2009: Soil forming effect of Grand fir (Abies grandis [Dougl. ex D. 
Don] Lindl.). Journal of Forest Science, 55 (12): 533-539.

Podrázský, V., Remeš, J., Hart, V., Keith Moser, W. 2009: Production and humus form development in forest stands estabilished on agricultural lands - Kostelec nad Černými lesy region. Journal of Forest Science, 55 (7): 299-305.

Posch, M., Smet, P. De, Hettelingh, J., DownING, R. 1995: Calculation and mapping of Critical Thresholds in Europe. RIVM Status Report, The Netherlands. $152 \mathrm{pp}$.

PRỦŠA, E. 2001: Pèstování lesů na typologických základech [Forest management on the basis of typology]. Praha, Lesnická práce: 593 s.

Purdon, M., Cienciala, E., Metelka, V., BeraNOVÁ, J., HunOvÁ, I., Černý, M. 2004: Regional variation in forest health under long-term air pollution mitigated by lithological conditions. Forest Ecology and Management, 195: 355-371.

SAMEc, P. 2008: Metody zpracování dat v lesnickém monitoringu [Approaches of Data Processing in Forestry Monitoring]. Kostelec nad Černými lesy, Lesnická práce: 132 s.

SAMEc, P., VAVŘ́íČEK, D., MACKŮ, J. 2008: Acidifikace versus pufrace lesních půd

[Acidification versus buffering of forest soils]. Lesnická práce, 58 (3): 341-343.

Slepetiene, A., Slepetis, J. 2005: Status of humus in soil under various long term tillage systems. Geoderma, 127: 207-215.

Smidt, S., Herman, F. 2004: Evaluation of air pollution-related risks for Austrian mountain forests. Environmental Pollution, 130: 99-112.

SPARKs, D. J. 2003: Environmental Soil Chemistry. London: Academic Press, Second Edition, $352 \mathrm{pp}$.

ŠÁLY, R. 1998: Pedológia. TU Zvolen: 180 s.

Ulbrichová, I., Podrázský, V. V., SlodičÁk, M. 2005: Soil forming role of birch in the Ore Mts. Journal of Forest science, 5l(Special Issue): 54-58.
VAVŘ́íčeK, D., ŠIMKOVÁ, P. 2000: Půdní prostř̌edí přirozených smrčin 8. LVS Krkonoš [The soil environment of natural spruce stands 8. forest altitudinal zone of Krkonose-Giant Mountains]. Opera Concortica, 37: 156-164.

VAVŘ́IĆEK, D. (2005): Some risks associated with surface liming of forest ecosystems at higher locations. In: VAVŘíčEK D., ŠimkovÁ P., SAMEC P., Formánek P. 2006: Soil aspects of forest site revitalization after windrow cultivation by heavy mechanization on the Krušné hory Mts. Plateau. Journal of Forest Science, 52 (1): 1-12.

VAVŘ́čEK, D. 2008: Stav půd vybraných území Krkonoš a Kněhyně v Moravskoslezských Beskydech [The soil condition in the area of the Krkonoše Mts. and Kněhyně Mt. in the Moravian-Silesian Beskids]. In: SAmec, P.: Metody zpracování dat v lesnickém monitoringu [Methods of data processing in forest monitoring]. $1^{\text {st }}$ ed., Folia Forestalia Bohemica. Lesnická práce, s.r.o., Kostelec nad Černými lesy: 33-44.

Vavř́íček, D., Pecháček, J., Staněk L., Pancová Šı̀KOVÁ, P. 2008: Soil taxonomical units and influence of species composition on selected qualitative humus parameters in the flysh belt of the National Nature Reserve Čertův Mlýn (6 th and 7 th forest vegetation belt). Beskydy: The Beskids bulletin, 1 (2): 199-208.

Vavě́ícé, D., Pecháček, J., Jonák, P., Samec, P. 2010: The effect of Point Application of Fertilizers on the Soil Environment of Spread Line Windrows in the Krušné hory Mts. Journal of Forest Science, 56 (5): 195-208.

Vesterdal, L., Dalsgaard, M., Felby, C., RaulunDRASMUSSEN, K., JoRgENSEN, B. B. 1995: Effects of thinning and soil properties on accumulation of carbon, nitrogen and phosphorus in the forest floor of Norway spruce stands. Forest Ecology and Management, 77: 1-10.

Waring, R. H., Running, S. W. 1988: Forest ecosystems: Analysis at multiple scales. San Diego (California), London (UK): Academic Press, $370 \mathrm{pp}$. 